\title{
American nurses in Europe
}

\section{Introduction: American nurses and the war in Europe}

Some nurse writers focused determinedly on the positive elements of military nursing, emphasising their own roles as effective humanitarian workers providing a highly professional service. Among these were Julia Stimson, a senior US nurse, and Helen Dore Boylston, a sister with the Harvard Unit. Yet the decision of such nurses to engage in the war ran counter to a powerful strain of pacifism in the writings of others. In August 1915, when Britain had been at war for a year, a $B J N$ editorial commented on the pacifist sentiments of prominent American nurse Lavinia Dock. The article was probably authored by the journal's editor, Ethel Gordon Fenwick, a close friend of Dock's. The two women had been instrumental in the foundation of the International Council of Nurses sixteen years earlier. ${ }^{1}$ Fenwick was firmly committed to the allied war effort; Dock, who was head of the American Journal of Nursing's 'Foreign Department', was unequivocally opposed to it. Nevertheless, Fenwick decided to publish 'the beautiful human ideals of this noble and lovable little woman': ${ }^{2}$

We have been asked why we do not record events happening in connection with the European War. So it may be time for us to remark that the Foreign Department, at any rate, intends to boycott this particular war. The only mention it will draw from us will be denunciation of 'war' as a specimen of man's stupidity. This war will get no advertising, no 'write ups', from the secretary of the International Council. It is a colossal piece of atavism - of return to the age of the tiger and the ape. ${ }^{3}$ 
Lavinia Dock was one of a radical breed of US nurse that was emerging at the beginning of the twentieth century. A Marxist, pacifist, and feminist, she coauthored, with Adelaide Nutting, an extensive history of nursing: a deliberately political text, stressing the significance of the nursing profession throughout the world. ${ }^{4}$ Born into a wealthy family, Dock had trained at Bellevue Hospital, New York, graduating in $1886 .{ }^{5}$ She had spent time working as a visiting nurse at the Henry Street Settlement on New York's impoverished 'Lower East Side', where she had, no doubt, come under the influence of the progressive Lillian Wald. ${ }^{6}$ She was a member of the New York Women's Trade Union League, and had been instrumental in setting up the American Nurses Association.?

Dock's openly anti-war writing has an important place among the works of female pacifists such as Catherine Marshall in Britain, and Charlotte Perkins Gilman in the USA, who deliberately linked pacifism to feminism by suggesting that war would be less likely in a world where women wielded political power. ${ }^{8}$ Open pacifism was, however, rare among nurses: most nurse writers contented themselves with exposing the horror of war in the hope that readers would draw their own conclusions. ${ }^{9}$

The American Army Nurse Corps had been founded in 1901 - a year before the formation of the British QAIMNS. It was, therefore, arguably well established by the time the USA entered the First World War in April 1917. And yet, its difficulties were similar to those encountered by the British service: subordination to a powerful military medical corps, the disadvantages associated with an entirely female workforce, and the prevailing social prejudices that linked female paid work with low social status. At the end of a pioneering era, the cultural values of US citizens were less elitist and its class system less entrenched than that in Britain. ${ }^{10}$ And yet chauvinism was rife, and some female senior nurses appear to have been subject to bullying and harassment by male medical colleagues. ${ }^{11}$ Paradoxically, the problem may even have been exacerbated by the relatively relaxed attitude to the class system in the USA. In Britain, their status as members of a gentry class may have offered nurses some protection. Kimberly Jensen, in her compelling paper 'A Base Hospital Is Not a Coney Island Dance Hall', presents a handful of clear examples of serious bullying on the part of medical officers, though it is unclear whether these can be viewed as typical. ${ }^{12}$ 


\section{Julia Stimson's 'splendid women'}

American nurse Julia Stimson appears to have had no difficulties in her relationships with medical officers. Her charismatic personality and apparently resolute refusal to see anything but good in any of her colleagues seems to have inoculated her against the problems encountered by some other senior nurses. Stimson was born in 1881, in Worcester, Massachusetts, into a wealthy family that clearly attached some importance to the education of women. She attended Brearley School in New York City and then the prestigious Vassar College in Poughkeepsie, New York. Following graduate studies in biology at Columbia University,

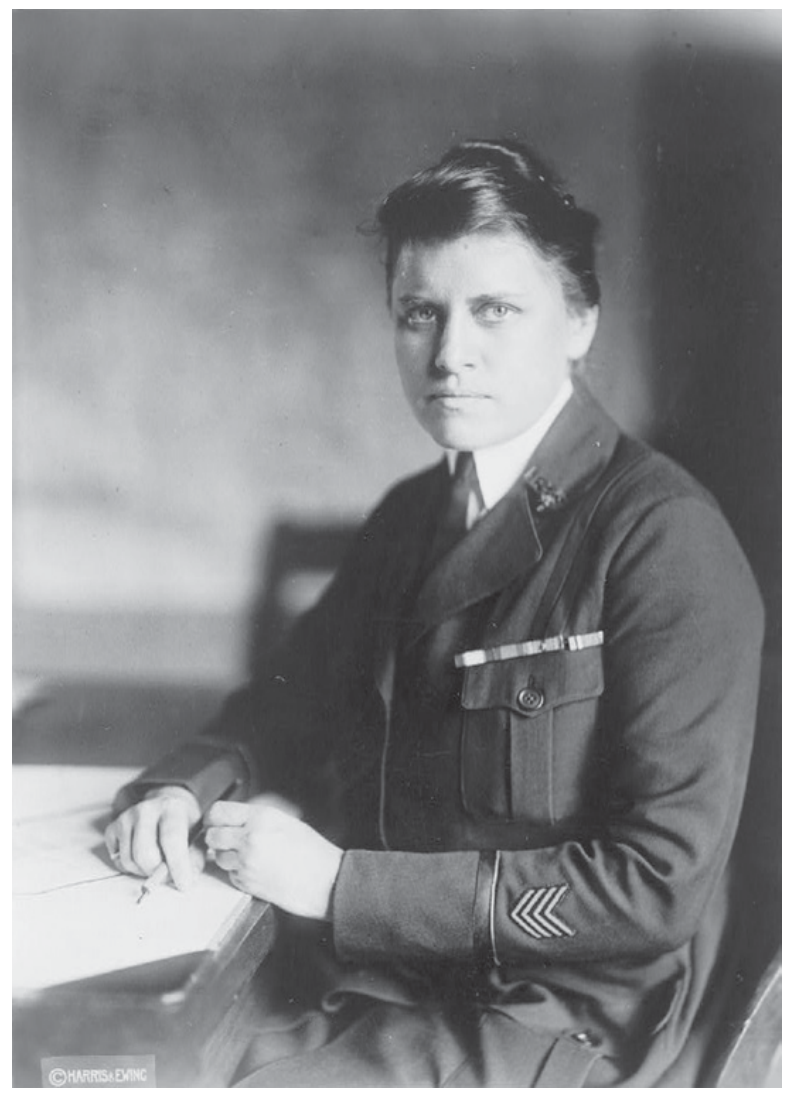

Figure 7 Portrait of Julia Stimson 
New York City, from 1901 to 1903, and nurse training at the New York Hospital School of Nursing, from which she graduated in 1908, she pursued a successful career, as superintendent of nurses, first at Harlem Hospital from 1908 to 1911, and then at Barnes Hospital, Washington University, St Louis, Missouri from 1911 to $1917 .{ }^{13}$

Between her two periods of service as a chief nurse, Stimson took on the role of Director of Hospital Social Service at Washington University, St Louis. ${ }^{14}$ It appears that a combination of her experience as a nurse and her awareness of the potential for philanthropy amongst the more privileged in society induced her to take a strong interest in social work. Such emphasis does seem to have been much stronger amongst American nurses at the turn of the century than amongst their British counterparts, finding its fullest expression in the work of the Henry Street Settlement from the 1890s onwards. ${ }^{15}$ And yet, Stimson cannot be viewed as a radical. Her concern for the poor existed within the confines of a conservative and traditional view of society. In many ways, her outlook was very similar to that of Kate Luard: the world was essentially as it should be, and it was not the role of the nurse to change it, but merely to alleviate the suffering that it must necessarily contain.

Julia Stimson's real genius was as a leader. She is said to have shown 'sheer generalship' during the First World War, ${ }^{16}$ and she appears to have achieved a remarkable level of harmony and success in her dealings with nurses and other professional colleagues. Her letters home were published in 1927 under the title Finding Themselves. ${ }^{17}$ They contain clues to Stimson's personality and leadership style. The respect and affection she felt for her junior colleagues was infused with both a maternal warmth and an air of authority.

Stimson was chief nurse of one of the earliest US units to arrive in France: Base Hospital No. 21, supplied by Washington University, St Louis. ${ }^{18}$ It took over an established British base hospital - No. 12 General Hospital, located on Rouen Race Course. ${ }^{19}$ The hospital was large, with up to 2,000 patients. When first invited to head its nursing services, Stimson effused in a letter home about the opportunity she had been offered. ${ }^{20}$ She expressed her 'tremendous satisfaction' at 'having a chance to ... be in the front ranks in this most dramatic event that ever was staged, and to be in the first group of women ever called out for duty with the United States Army, and in the first part of the army ever sent off in an expeditionary affair of this sort. ${ }^{21}$ Stimson's 
language, her reference to the war as a 'dramatic event' that was being 'staged', and her emphasis on being 'the first' speaks of her focus on both attainment and recognition. Sheila Rowbotham has observed that 'when they encountered opposition to their engagement in the public arena, middle class and working class women invoked motherly care, moral cleansing and class loyalty to justify stepping beyond the prescribed "womanly" sphere. ${ }^{22}$ Julia Stimson is a classic example of a woman who presented herself in a traditional female 'nurturing' role, while exercising enormous authority within a military setting.

Stimson's letters contain repeated expressions of concern for her staff - a concern that is mingled with admiration. On 17 June 1917, she remarks: 'my women are splendid. A few, of course, have periods of rearing, but they all have steadied down most beautifully. ${ }^{23}$ Stimson's tendency to write of her 'splendid women' as though they were horses who had to be broken in carries interesting undertones of the pioneering spirit of a unit from the Mid-West of the USA. Her equestrian metaphor illustrates how carefully Stimson 'handled' her nursing staff: as one might handle creatures with little sense of autonomy but much emotional volatility. She adds that she is 'proud of the spirit of cooperation' amongst her staff, and that she fosters this by posting poems on bulletin boards 'about the meaning of the war and the ideals we are fighting for'. She concludes: 'I certainly have some wonderfully splendid women with me. Some of them have queer exteriors and some queer ways, but they are fine with me..24 The tendency to post material on bulletin boards that a modern readership might identify as propagandist offers further evidence of Stimson's traditionalist perspective. The fact that she did not question the motives of the allies undoubtedly contributed to her strong and authoritative persona.

Stimson's ability to command the respect and affection of her staff and to sustain morale was clearly one of her strengths. But her involvement with them went much further than a desire to control their behaviour. One of her letters recounts how:

Ruth C- has just been in to see me a moment. She is on night duty and is working very hard. She says there never in the world were such wonderful patients, that no matter how much they are suffering they are 'quite all right thank you, Sister', and they won't ask for things, and when she asks them if they are in pain, they say, 'Not too much, Sister'. The first night she says she went all to pieces, but nobody saw her; now she too is getting steadier. ${ }^{25}$ 
In the same letter, she comments that her nurses 'are beginning to show the effect of the emotional strain', adding, 'I have had about a dozen of them weeping.' She misses her own friends: 'naturally I cannot do any weeping here, since I have to be wept on; but there are times when it would be such a comfort to be braced myself'. ${ }^{26}$ The desire to 'be braced' is characteristic of many of those who nursed the wounded during the First World War. Being a part of the army medical services (regardless of which army one was attached to) meant a lack of freedom to determine one's own movements or actions, whilst 'active service' meant an intensity of work that could be exhausting. Yet, many expressed their determination to 'stay at their posts', because the men they nursed had no choice but to do so. ${ }^{27}$ Eventually, for some, the stress became almost unbearable:

There was nothing really wrong on Sunday, but that day we had so many sick men to look after, and things got a bit complicated and several nurses got hysterical and I felt things were just too much. Any one would have thought so if they had seen our poor gassed men who are so terribly burnt. One of my most stolid nurses came to me that day and said 'I just don't know how I am going to stand it, taking care of so and so.' I said 'Why not?' and she replied, 'When he was brought in to us he was so badly burned we could hardly see any part of him that we could touch except the back of his neck; but that isn't the worst part, instead of cursing or moaning he was singing, and I just can't stand that. ${ }^{28}$

The theme of the courage and endurance of the patients recurs regularly in Stimson's - as in other nurses' - testimony. It seems to have evoked a strong desire in nurses to emulate their patients' stoicism. One result of this was the eventual 'breakdown' of some members of staff. On 6 April 1918, Stimson wrote home to her parents that she had three nurses in hospital themselves: 'one with diphtheria, one with a kind of trench fever due to exhaustion, and the third, my dear, brave soul who came down from the evacuated CCS. She has just "exhaustion" for a diagnosis. ${ }^{29}$ She adds how remarkable it is that more nurses are not ill. One of her most poignant narratives is of a nurse she observes caring for a dying patient:

It was getting dark as I went down between the A and B lines of tents. Ducking under the entrance of A.3 tent, I stopped just a moment inside the door, to get used to the darkness in the tent. The fourteen beds in the tent were all full and I thought at first that no nurse was there. Then I saw 
her. She was kneeling beside the low cot of a lad whose whole head was bandaged. The tight starch bandage covered his ears and his eyes, and came down under his chin. A glance at his face showed that he was not far from the end. 'Robert, lad, what are you trying to say?' she was asking, bending over him with her arm across his shoulder and her face close to his lips. 'Say it again, boy, so that I can hear you. Did you want me to do something for you?' Slowly pulling his arms out he reached up and drew her head down to his and kissed her on the cheek. 'I think', he said, 'you must be like my sister'. Just then she saw me. 'Oh, excuse me Matron', she said as she rose, 'I didn't hear you come in.' We walked through to the connecting tent while the other thirteen men stirred and pretended to wake up. ${ }^{30}$

In 1918, Stimson's abilities as a leader were rewarded by her appointment as chief nurse of the American Red Cross in France. Later that year, she was transferred to the directorship of the Nursing Services for the American Expeditionary Force. ${ }^{31}$ Her ability as a diplomat was a significant element of her impressive battery of skills. After the war, she was appointed Dean of the Army School of Nursing, a position she held until the school's closure in 1931, when she continued as superintendent of the Army Nurse Corps. In 1920, US Congress awarded army nurses relative rank, and Stimson was given the title of major. Six weeks before her death, in 1948, she was promoted to the rank of colonel (retired). ${ }^{32}$ For Julia Stimson, there were no barriers to success or advancement. Her remarkable sense of duty and her capacity for working within the systems devised by others - and for making those systems work, through the force of her charisma and personality - ensured that she enjoyed a level of success and a recognition not afforded to many nurses in the first half of the twentieth century.

\section{Pioneer nurse: the adventures of Helen Dore Boylston}

Many US nurses appear to have relished the excitement of journeys 'into the unknown' - none more so than Helen Dore Boylston, a young nurse with the Harvard Unit, who spent the last two years of the war on the Western Front and the remainder of her life writing about the adventure of nursing.

Boylston was born in Portsmouth, New Hampshire, in 1895, when the United States of America was at the height of its pioneering 
powers. Looking both eastwards to the sophistication and style of fin-de-siècle Europe and westwards towards a half-tamed wilderness, Eastern-Seaboard America was a place of unlimited opportunity, and Boylston was its creature, participating fully in its possibilities and experiencing its contradictions with the keenness of a popular writer. Her book 'Sister': The War Diary of a Nurse was developed from a journal she kept during her time on the Western Front; but it found its final form whilst she was living a bohemian life in 1920s Albania with her close friend, confidante, and fellow-author, Rose Wilder Lane. ${ }^{33}$

Boylston's restless spirit, her constant quest for new experience, and her thirst for travel and adventure found expression in her recounting of her wartime experiences. It may seem surprising that nurses on the Western Front could find time and opportunity - given their difficult living conditions and long working hours - to keep full and detailed diaries. Yet, archives around the world are filled with their journals, accounts that have clearly been written contemporaneously with the events they describe - on mud-streaked paper, in tiny notebooks, often beginning with fine ink, and ending in blunt pencil. ${ }^{34}$ Books such as 'Sister' were the product of such meticulous diary-writing. Yet Boylston's memoir, like many others, is also, in some ways, remote from the incidents it describes. Its very clarity and simplicity belie the complexity of war nursing. It has clearly been edited and modelled to tell a particular story.

Helen Dore Boylston's father was a successful physician. It has been suggested that she herself considered training as a doctor, but chose nursing instead because the training was shorter. ${ }^{35}$ This story may be apocryphal, but it fits with the character of a restless spirit, who clearly had no desire to be trapped in one place. She trained at one of the most prestigious North American Hospitals - the Massachusetts General Hospital, Boston - and, like Alice Fitzgerald and Julia Stimson, benefited from her upper-middle-class background, moving easily through the social milieu of this powerful institution.

Boylston was clearly at ease with herself, and this enabled her to form easy relationships with others. In northern France, she appears to have enjoyed friendships with both fellow nurses and medical officers. There is no trace in her story of elitism or snobbery. In her world, nurses, medical officers, and orderlies work in harmony, enjoy 
dark banter during German raids, and go off together on picnics and excursions. It may be that this world is a partly fictional one. As we have seen, the researches of Kimberley Jensen have suggested that the American Army Nurse Corps experienced more than its share of chauvinism - particularly at senior levels - and that, at times, this bordered on bullying and harassment. ${ }^{36}$ Yet, Boylston's experiences concur with those of Julia Stimson, whose personal charm and traditional outlook on women's roles assured her a smooth social passage through the troubled waters of the American military hospital. For Boylston, it was not traditionalism, but a largely unconscious radicalism and feminism that enabled her to experience her time on the Western Front as one of camaraderie. She appears to have found chauvinism and snobbery a source of humour - something either to ridicule or to ignore.

'Sister' reads as a succession of highly entertaining vignettes of Boylston's time in northern France. The tone is light - remarkably so when one considers the nature of the subject-matter. Decades after the war, Boylston was to carve out a successful career as a writer of books for teenage girls; it may be that in the 1920s, when crafting 'Sister', she was already developing her popular style of novel writing. The narrative speaks through a strong, resonant voice, with a tone of muted humour. Boylston appears to have been, above all else, a powerful and completely natural story-teller.

The Harvard Unit - consisting of doctors, trained nurses, and male orderlies - was said by Alice Fitzgerald to have arrived in France at the end of May 1917. ${ }^{37}$ After spending some time in Camiers, 'with leaky huts and no drainage, ${ }^{38}$ it took over the site of the No. 13 General Hospital in Boulogne - where Fitzgerald had been serving with the BEF. The British relinquished their hospital with great reluctance, and Fitzgerald commented in her diary that 'there is much hard feeling over the whole affair', with British staff denouncing the behaviour of 'those dreadful Americans from the Harvard Unit. ${ }^{39}$ Boylston appears to have been largely unaware of these tensions. Her account focuses on her own individual adventures - such as a terrible throat infection, which is cured when one of her colleagues lances the abscess with an iodine-soaked probe; ${ }^{40}$ or a battle with rats in her ward, which she wins with the assistance of the hospital's terrier, Toodles. ${ }^{41}$ Romance also finds a place in her memoir - but it 
takes a light and humorous form. Friendship seems more important, with Boylston and her friends finding great pleasure in each other's company on long walks. ${ }^{42}$

Boylston's text offers simple, vivid descriptions of a world in which she takes an eager, yet relaxed, interest. One passage, written while waiting for night duty to begin, offers a nostalgic reflection on how life in a French base hospital reminds Boylston of camping in Maine:

The smoky smell in the air is making me a little homesick for the old days when I went fishing down in the Maine woods with Dad. I remember the smell of the hot pine-needles and dry leaves and burnt underbrush; the great broad lake, blue and motionless in the summer heat; the dry buzz of insects; and the nights, the beautiful, lonely nights when the lake was full of stars and the woods lay heavy with blackness along the shores, and there was no sound except the far-off call of a loon, or the sad, questioning 'Quosh?' of a blue heron sweeping through the night ... How far away and long ago it seems! I wonder sometimes if it really happened. I wouldn't go back. I wouldn't give up these days in France, but I can't help remembering when there is a smell of wood-smoke in the air. ${ }^{43}$

Boylston's skill lies in the simplicity of her sentences. The pathetic fallacy achieved by juxtaposing the camp fires of a military base hospital with the smoky smell of a peaceful lakeshore in Maine evokes a sense of nostalgia and creates a mood of peaceful longing for something the reader can sense but not fully understand. This passage is followed immediately by a humorous one, in which nurses, British VADs, and medical officers take a walk 'carrying steamer-rugs and poetry', and in which 'an ardent VAD [begins] a frenzied pursuit of one of our shyest medical officers. ${ }^{4}$

In May 1918, soon after the commencement of the German counter-offensive on the Western Front, Boylston's unit became the target of a series of relentless bombing raids. It is not known what she actually wrote in her diary during this time, but, years later, sitting at her table in the Albanian residence she was sharing with Rose Wilder Lane, she chose to model these events into a remarkable adventure. Some of the episodes in her memoir could almost have been lifted straight out of a 'girl's own adventure' story. One example recounts an episode when the hospital is bombed from the air by German Gothas. The episode begins with Boylston working with a medical officer, 
caring for a dying patient. They hear the guns at Boulogne, and then the approach of the German planes:

'Good God!' Eddie said. 'We're in for it!'

At that instant there came a flash from the beach, a long whistling sigh, a terrific jar, and then a faint $b$-o-o-ng directly overhead. Archie had spoken! A moment later every gun for miles around had turned loose and was firing frantically, the shells whining in a dozen different keys. And all the time, hiss-ss-ss, a tremendous shock, and a blinding red glare. The planes circled closer and closer, until even the machine-guns opened fire on them, with their ridiculous put-put-put. It was horrible, and yet it had a kind of dreadful beauty - the searchlights swinging and crossing; the yellow blaze of flares and star-shells; the lightning flash of the guns; and sometimes a great gold bug swooping out of the sky - Fritz, caught in the searchlights. Or again, a hideous black bug moving against the moon.

The boys, terrified, were beginning to shout for 'sister', and I ran across to B5, where they were the most helpless. Eddie followed me, and we walked up and down between the beds, trying to quiet the boys by appearing calm ourselves. They were frantic with terror, and I can't say that I was much better. ${ }^{45}$

Boylston describes how, later, while moving between wards, she is almost caught in the blast of an exploding shell. She writes of 'living ten years' as she waits for the bomb to land, and then of seeing a 'blood-red flare' even with her hands over her closed eyes, and of feeling earth and stones 'pattering down'. She adds: 'When I crawled to my feet I found that I was shaking all over, which surprised me, for I was still not conscious of any particular emotion. ${ }^{46}$

The apparent simplicity of Boylston's style belies her skill in creating a text that draws in the reader, sustaining a feeling of suspense while presenting a succession of highly visual images. The text has an auditory quality too: reading a narrative that contains the ' $b-o-o-n g$ ' of heavy artillery, the 'hiss-ss-ss' of shrapnel, and the 'put-put-put' of machine guns conveys a feeling of having returned to childhood - of listening to a story read aloud. It is not difficult to understand why Boylston later became a successful children's novelist. Far from recreating a Western-Front base hospital, these images construct something entirely original. In the style of G. A. Henty, they enable the reader to experience vicariously the excitement of war without being tarnished by its grimmer realities. ${ }^{47}$

Many nurses belonging to US hospital units during the First World War wrote diaries, but very few ever intended their works to 
be published. Canadian-born Ella Mae Bongard travelled to France as a fully trained member of a medical unit sent out by the Presbyterian Hospital of New York, and was posted to Etretat on the French coast. Her diary does not appear to have been written with publication in mind, and was, in fact, only published many years after her death, by her son, Eric Scott. Her diary entries offer an interesting contrast to Boylston's deliberately engaging story-telling:

January 22, \& 23, 1918. I feel a little like Lady Macbeth these days - 'Tomorrow \& Tomorrow \& Tomorrow creeps in this petty pace from day to day' etc. But of course I know it's just night duty. The other night I was sent up to officers to special a very sick man. He was a young aviator of $19 \&$ he had one leg off, the other one fractured, a fractured skull and was then developing tetanus. It hardly seems fair for one person to have to go through so much. That was about a week ago and now I hear that he is a little better and they have some hopes of his recovery. He may want to live but I don't believe I should under the circumstances. ${ }^{48}$

Bongard's writing conveys a quiet calmness, its laconic phrases contrasting with Boylston's adventure-writing style.

Helen Dore Boylston's 'Sister' ends with the armistice, and Boylston's reaction to peace is characteristic:

November 11.

In ten minutes the war will be over. Hostilities are to cease at eleven oclock, and it is ten minutes to eleven now ...

There go the bells! And the drums! And the sirens! And the bagpipes! And cheering that swells louder and louder! The war is over - and I never felt so sick in my life. Everything is over.

But it shan't be! I won't stop living. ${ }^{49}$

Boylston's outburst - so different in both perspective and style to many other nurses' reminiscences of the armistice - offers a clear insight into her thirst for variety and adventure. And yet she was not unique. Many of those who had experienced both the excitement and the horror of wartime nursing were unable - often for reasons they could not express - to return to civilian nursing after the armistice. Many left nursing altogether. Others moved into relief work. ${ }^{50}$ Boylston herself spent several years after the war working for the Red Cross in Albania, Poland, Russia, Italy, and Germany. Yet, ultimately Red Cross relief work was no more satisfying than civilian nursing, and she returned to the Massachusetts General Hospital. ${ }^{51}$ 
Boylston met fellow Red Cross worker Rose Wilder Lane on a train from Paris to Warsaw in 1920, and the two became close friends. Both craved adventure and longed for a more independent way of life. By the mid-1920s they had formed a plan to travel overland in a Model T Ford from Paris to Albania, to establish a home in a land free from the constraints of western power-politics and bureaucracy. ${ }^{52}$ Boylston had already spent time in Albania working for the Red Cross and had convinced Lane that Albanian culture was pure and unsullied free from both the corrupt political and imperialist forces that had almost destroyed Europe and the 'crassly commercial' atmosphere of the USA. ${ }^{53}$

Lane was the rebellious and talented daughter of Laura Ingalls Wilder, who would later become famous as author of a series of books including The Little House on the Prairie. ${ }^{54}$ Boylston, although eight years her junior, was clearly the more adventurous of the two; she was the expedition's driver and car-mechanic. The addition of the women's French maid, Yvonne, meant that an unlikely trio of friends made their way through France and Italy during the summer of 1926.

For biographer William Holtz, Boylston and Lane personified American confidence and materialism. Their relationship with their car, which they named 'Zenobia' and wrote of as though it were a human being, was a classic example of the 'American love affair with the automobile. ${ }^{55}$ As they travelled through Europe, the two women composed a series of long, jointly written letters home, sending copies to their families, and to their stockbroker and close friend, George Palmer. Put together, these letters provide an account of their deliberately intrepid journey. Through Holtz's edited text, a modern reader can learn of their adventures in France, of the dangers they faced in the Italian Apennines, of the dismay they felt when almost all of their possessions were stolen in Naples, and of the idiosyncrasies of peasants in various lands, all of whom are presented as humorous stereotypes. ${ }^{56}$ For Holtz, the women's pursuit of adventure was deeply influenced by 'their commitment to a vision of America as a special case in history, a chosen land in which a chosen people would forge a great nation by simply pursuing their individual destinies..$^{57}$

Throughout the story, Boylston is referred to as 'Troub', the nickname she had been given by her colleagues in the Harvard Unit. ${ }^{58}$ The 
highlight of the women's journey is reached towards its end, when 'Troub' drives Zenobia from a small sailing-boat onto the harbour of Durazzo, across two narrow planks that bend and crack under the automobile's wheels:

When I saw her she stood there swaying. Two planks, eight inches wide, had been inserted under her front wheels, and led upward at an acute angle to the edge of the wharf. Under them the lapping water licked its lips. Troub was at the wheel, enclosed in the glass box of that sedan. On the wharf a wild-eyed Yvonne clutched all our purses and stared, frantic. Some twenty or thirty Albanians swarmed over Zenobia and the sail boat, tipping the boat, the car and the planks first to one side and then far to the other. I expected the whole thing to capsize momentarily. ${ }^{59}$

The two women remained in Albania for less than two years. Returning to America, and to the disastrous stock-market crash of 1929, each found herself in need of regular employment. Boylston returned, once more, to nursing, pursuing a successful career at the Massachusetts General Hospital and in Connecticut. ${ }^{60}$

Eventually, in the 1930s, Boylston found fame writing books for teenage girls: firstly relating the adventures of 'Sue Barton', an American nurse, ${ }^{61}$ and then of romantic 'Carol Page', a successful actress. ${ }^{62}$ Perhaps 'Troub' herself was as much an actress as a nurse, presenting herself as 'the all-American [girl] of magazine fiction. ${ }^{63}$ This act was convincing because she herself believed so fully in it. Yet, Deborah Philips asserts that Boylston's Sue Barton books, for all their 'pioneer' spirit, offer a realistic, rather than romanticised, vision of nursing ${ }^{64}$ providing an important impetus to the growing conviction amongst young girls that their careers mattered. For Sue, her love of nursing takes precedence over her love of handsome doctor Bill Barry. Although their romance simmers through the first three books in the series, it is not until the fourth, Sue Barton, Rural Nurse, that Sue consents to marry Bill. ${ }^{65}$ Helen Dore Boylston's own determination to make her mark in the world was probably influenced by her upbringing in a wealthy but active professional household. Her father had taken her on camping trips in the Maine countryside an activity normally reserved for boys - and had encouraged her to 'show the world what you can do before you settle down. ${ }^{66}$ Boylston appears to have taken his advice so seriously that she never really did 'settle down'. 


\section{Conclusion: far-off lands and strange adventures}

The published memoirs of First World War nurses sometimes read like travelogues. For Julia Stimson, service with the ANC meant a loss of control over her own life - a prospect that she found exciting. One of her earliest letters comments on the thrill of not knowing where in the world she is to be posted. Upon finding herself in France, she appears to have revelled in the challenge of supervising a nursing staff in a new and strange environment. For Helen Dore Boylston, the travelling never seems to have stopped - or, at any rate, it lasted for as long as her funds would allow. It was only the stock-market crash of 1929 and the need to stay in one place and earn a living that turned her adventurous spirit inwards to the writing of children's fiction. Many early-twentieth-century women appear to have experienced a compulsion to travel, ${ }^{67}$ a compulsion that was perhaps most clearly expressed in Rose Wilder Lane's description of an Albanian sunset:

The mountains were sliced off along their tops, neatly, in a straight line, by a dark blue mist that covered the eastern sky. Beneath this line, between the nearer mountain peaks, the far valleys and farther mountain peaks were revealed in sunshine. They were vaguely beautiful - something as lovely as our waking dreams of lands we shall never see. We continue to cling to the belief that when we see them they will be beautiful, but an implacable circle of reality moves with us wherever we go. ${ }^{68}$

The longing to move beyond their 'circle of reality' drove many women to offer their services as nurses in the First World War. For others, it was patriotism that moved them. Their travels - though experienced as exciting, and described in terms of wonderment were incidental to their desire to serve in the Great War: the greatest event in living memory and the conflict to which so many brothers, friends, and lovers had committed themselves. For many, their experiences brought satisfaction in service. For others, the war left them with an unfulfilled longing - to see the 'farther mountain peaks'.

\section{Notes}

1 Fenwick was first president and Dock first secretary to the International Council of Nurses: Barbara Brush, Joan Lynaugh, Geertje Boschma, Anne Marie Rafferty, Meryn Stuart, and Nancy J. Tomes, Nurses of All Nations: A History 
of the International Council of Nurses, 1899-1999 (Philadelphia: Lippincott, Williams, and Wilkins, 1999).

2 Anon., Column, BJN (7 August 1915): 118-19 (119).

3 Lavinia Dock, Column published in the American Journal of Nursing, quoted verbatim in BJN (7 August 1915): 118-19.

4 M. Adelaide Nutting and Lavinia L. Dock, A History of Nursing: The Evolution of Nursing Systems from the Earliest Times to the Foundation of the First English and American Training Schools for Nurses, 4 vols (New York and London: G. P. Putnam's Sons, 1907-12).

5 Deborah Philips, 'Healthy Heroines: Sue Barton, Lillian Wald, Lavinia Lloyd Dock and the Henry Street Settlement', Journal of American Studies, 33.1 (1999): 65-82.

6 Although Dock was probably the more radical of the two: Philips, 'Healthy Heroines'.

7 Philips, 'Healthy Heroines'.

8 Catherine Marshall, Militarism versus Feminism (London: Virago, 1987 [1915]); Charlotte Perkins Gilman, Herland (New York: Pantheon, 1979 [1915]). On the work of Charlotte Perkins Gilman, see: Claire Tylee, The Great War and Women's Consciousness: Images of Militarism and Womanhood in Women's Writings, 1914-64 (Houndmills and London: Macmillan, 1990): 41. Tylee also comments on the writings of Olive Schreiner, who states that 'the day that women shared in government with men would be the day that heralded the death of war' (41).

9 This was a particular trait in the writings of British and Dominion nurses. See: Kate Finzi, Eighteen Months in the War Zone: The Record of One Woman's Work on the Western Front (London: Cassell, 1916); Irene Rathbone, We That Were Young: A Novel (New York: The Feminist Press, 1989 [1932]); May Tilton, The Grey Battalion (Sydney: Angus and Robertson, 1933).

10 Margaret Deland, Small Things (New York: D. Appleton, 1919): 8.

11 Kimberly Jensen, Mobilizing Minerva: American Women in the First World War (Urbana and Chicago: University of Illinois Press, 2008), Chapter 7, 'A Base Hospital Is Not a Coney Island Dance Hall: Nurses, Citizenship, Hostile Work Environment and Military Rank': 116-41.

12 Jensen, Mobilizing Minerva: 116-41. See also: Kimberly Jensen, 'A Base Hospital Is Not a Coney Island Dance Hall: American Women Nurses, Hostile Work Environment, and Military Rank in the First World War', Frontiers, 26.2 (2005): 206-35.

13 Alice Howell Friedman, 'Stimson, Julia Catherine', in Martin Kaufman (ed.), Dictionary of American Nursing Biography (New York: Greenwood Press, 1988): 350 .

14 Friedman, 'Stimson, Julia Catherine': 350.

15 Karen Buhler-Wilkerson, No Place like Home: A History of Nursing and Home Care in the United States (Baltimore: Johns Hopkins University Press, 2001). 
16 Friedman, 'Stimson, Julia Catherine': 350-1.

17 Julia Stimson, Finding Themselves: The Letters of an American Army Chief Nurse at a British Hospital in France (New York: Macmillan, 1927).

18 Mary T. Sarnecky, A History of the US Army Nurse Corps (Philadelphia: University of Pennsylvania Press, 1999): 83.

19 Stimson, Finding Themselves: frontispiece; Jensen, Mobilizing Minerva: 136.

20 Stimson, Finding Themselves: 3-4.

21 Stimson, Finding Themselves: 3-4.

22 Sheila Rowbotham, Dreamers of a New Day: Women who Invented the Twentieth Century (London: Verso, 2010): 2.

23 Stimson, Finding Themselves: 63.

24 Stimson, Finding Themselves: 63.

25 Stimson, Finding Themselves: 43-4.

26 Stimson, Finding Themselves: 92.

27 Christine Hallett, Containing Trauma: Nursing Work in the First World War (Manchester: Manchester University Press, 2009): 194-218.

28 Stimson, Finding Themselves: 93.

29 Stimson, Finding Themselves: 220.

30 Stimson, Finding Themselves: 223.

31 Friedman, 'Stimson, Julia Catherine': 350-1.

32 Sarnecky, A History of the Army Nurse Corps: 100-1. See also: Friedman, 'Stimson, Julia Catherine': 351.

33 Helen Dore Boylston, 'Sister': The War Diary of a Nurse (New York: Ives Washburn, 1927). The diary was, initially, serialised as "Coming of Age", in the popular journal Atlantic Monthly, from September to November 1925: William Holtz (ed.), Travels with Zenobia: Paris to Albania by Model T Ford (Columbia and London: University of Missouri Press, 1983): 6-7, 9.

34 Santanu Das, Touch and Intimacy in First World War Literature (Cambridge: Cambridge University Press, 2005): 175-203; Hallett, Containing Trauma: 10-15.

35 Holtz, Travels with Zenobia: 6.

36 Jensen, 'A Base Hospital Is Not a Coney Island Dance Hall'.

37 Although there is evidence that a unit from Harvard University was in France much earlier than this. Alice Fitzgerald, unpublished memoirs incorporating war diary, c. 1936, Alice Fitzgerald Papers, Md HR M2633, Md HR M 2634, Maryland Historical Society Archives, Baltimore, Maryland, USA.

38 Fitzgerald, unpublished memoirs.

39 Fitzgerald, unpublished memoirs.

40 Boylston, 'Sister': 88-9.

41 Boylston, 'Sister': 93-4.

42 Boylston, 'Sister': 86-7.

43 Boylston, 'Sister': 90-2. 
44 There is evidence that contingents of British VADs were left in general hospitals following their evacuation by their British units, until fully trained American 'reinforcements' could be brought from the USA: Boylston, 'Sister': 92.

45 Boylston, 'Sister': 97-103.

46 Boylston, 'Sister': 102.

47 G. A. Henty, The Collected Works of G. A. Henty, 7 vols (Alvin, TX: Halcyon Classics, 2011). On G. A. Henty, see: Mawuena Kossi Logan, Narrating Africa: George Henty and the Fiction of Empire (London: Taylor and Francis, 2007).

48 Eric Scott (ed.), Nobody Ever Wins a War: The World War I Diaries of Ella Mae Bongard, R.N. (Ottawa: Janeric Enterprises, 1997): 29.

49 Boylston, 'Sister': 173-4.

50 Christine E. Hallett, Veiled Warriors: Allied Nurses of the First World War (Oxford: Oxford University Press, 2014): Conclusion.

51 Philips, 'Healthy Heroines': 65-82; Holtz, Travels with Zenobia: 6-7.

52 Their letters are edited by William Holtz, who also offers numerous insights into their backgrounds and motivations: Holtz, Travels with Zenobia: passim.

53 Holtz, Travels with Zenobia: 6-7, 10.

54 Little House on the Prairie was one of a highly successful series of children's novels recounting Wilder's childhood as part of a pioneering American family. On the careers of both Laura Ingalls Wilder and Rose Wilder Lane, see: Holtz, Travels with Zenobia: 2-5.

55 Holtz, Travels with Zenobia: 12.

56 Holtz, Travels with Zenobia: passim.

57 Holtz, Travels with Zenobia: 20.

58 It is probable that she first acquired this nickname in childhood. See: Holtz, Travels with Zenobia: 5.

59 Holtz, Travels with Zenobia: 88-9.

60 Philips, 'Healthy Heroines': 67.

61 Boylston wrote thirteen highly successful children's books. The 'Sue Barton' series consists of: Sue Barton, Student Nurse (1936); Sue Barton, Senior Nurse (1937); Sue Barton, Visiting Nurse (1938); Sue Barton, Rural Nurse (1939); Sue Barton, Superintendent of Nurses (1940); Sue Barton, Neighbourhood Nurse (1949); Sue Barton, Staff Nurse (1952). All went into several editions and reprints.

62 The 'Carol' books are: Carol Goes Backstage (1941); Carol Plays Summer Stock (1942); Carol on Broadway (1944); Carol on Tour (1946); Carol Goes on the Stage (1947). Boylston is believed to have obtained material for these novels from an actress friend, Eva Le Galliene. She also wrote a biography of famous Civil War volunteer nurse Clara Barton: Helen Dore Boylston, Clara Barton: Founder of the American Red Cross (New York: Random House, 
1955). On Helen Dore Boylston as a children's author, see also: Sally Mitchell, 'Helen Dore Boylston', in Lina Mainiero (ed.), American Women Writers (New York: Frederick Ungar, 1979): 209-11; Brian Doyle (ed.), The Who's Who of Children's Literature (New York: Schocken Books, 1968): 35.

63 Holtz, Travels with Zenobia: 22.

64 Philips, 'Healthy Heroines': 78.

65 Helen Dore Boylston, Sue Barton, Rural Nurse (New York: Image Cascade, 2008 [1939]).

66 Philips, 'Healthy Heroines': 81.

67 On travel literature, see: Alan Ogden, 'Romanian Culture in the Twentieth Century: The View of English Travel Writers before the Second World War', Romanian Civilization, 19.3 (2000): 44-54; Alba Amoia and Bettina Knapp, Women Travel Writers: From 1750 to the Present (New York: Continuum, 2005); Richard De Ritter, 'Reading "Voyages and Travels": Jane West, Patriotism and the Reformation of Female Sensibility', Romanticism, 17 (2011): 240-50; Juanita Cabello, 'On the Touristic Stage of 1920s and '30s Mexico: Katherine Anne Porter and a Modernist Tradition of Women Travel Writers', Women's Studies, 41.4 (2012): 413-35.

68 Holtz, Travels with Zenobia: 99. 